\title{
Reinventando a história de Olympe de Gouges
}

\author{
Eu vivi por um sonho.
}

CUTRUFELLI, Maria Rosa.

Tradução de Maurício Santana Dias.

Rio de Janeiro: Record, 2009.

Eu vivi por um sonho, cujo título original é La donna che visse per un sogno (A mulher que viveu por um sonho), é um dos romances da escritora italiana Maria Rosa Cutrufelli, publicado em 2004, na Itália, e o primeiro dela a chegar ao mercado editorial brasileiro. A tradução fica a cargo de Maurício Santana Dias, que vem cada vez mais se destacando como um influente elo entre Brasil e Itália.

Maria Rosa Cutrufelli nasceu em Messina, na Sicília, uma região que já deu grandes autores, uns mais, outros menos canônicos, para a literatura italiana. Só para lembrar alguns nomes, Giovanni Verga, Luigi Pirandello, Vitaliano Brancati e, mais recentemente, Leonardo Sciascia, Vincenzo Consolo, Andrea Camilleri. Sem se esquecer de que a literatura italiana teve sua origem com a escola poética siciliana, que será recuperada depois por Dante Alighieri e pelos poetas toscanos.

Formada em Letras pela Universidade de Bolonha, Cutrufelli hoje mora na capital romana e, além da atividade de escritora, colabora com a RAI (Radiotelevisão Italiana) e com várias revistas literárias. É uma das fundadoras da revista Tuttestorie, que dirigiu por 12 anos. A temática da narrativa feminina e os estudos de gênero, presentes em vários números dessa publicação, são aspectos constantes que acompanham a sua escritura, como pode ser identificado nos vários ensaios sobre a condição da mulher na sociedade, por exemplo, "Il cliente - inchiesta sulla domanda di prostituzione", de 1981 ("O cliente - a pesquisa sobre a procura de prostituição"). Esses aspectos também estão marcantes nas suas aventuras ficcionais. Podem ser lembrados aqui Mamma Africa (1989), um livro de memórias autobiográficas, e La Briganta (1990), cuja protagonista é uma mulher que deve enfrentar todas as dificuldades por ser diferente e não seguir as "normas impostas". Outra obra, Complice il dubbio (1992), foi adaptada para o cinema com o título Le complici, em 1998, pela cineasta Emanuela Piovano.

Em Eu vivi por um sonho, Cutrufelli recupera a "fórmula" do romance histórico, tão em voga na segunda metade do século XX e no início do século XXI. O convite da autora ao leitor é voltar ao século XVIII, na França, mais precisamente na Paris de Robespierre, um país devastado pela revolução e desgovernado pelas rebeliões. Nesse quadro, a guilhotina é o símbolo máximo da ordem, que intimida e desencoraja por meio do terror e da morte aqueles que tentam lutar por uma sociedade de indivíduos livres e iguais. Dentre esses se sobressaem a figura e a voz de Olympe de Gouges, a autora da "Declaração dos direitos da mulher e da cidadã" (1791), um título que retoma o da declaração feita pelos homens. No texto de Olympe, são reivindicados a igualdade de direitos para as mulheres, sua representação no parlamento, o direito ao trabalho e à igualdade de salário, o direito à propriedade para as mulheres casadas e a reforma das leis matrimoniais; e são também assinaladas obrigações como a igualdade penal para os sexos. Vale lembrar que esses ideais foram ainda motivados pelo lema da Revolução Francesa, anterior de dois anos, de 1789: igualdade, liberdade, fraternidade.

A de Olympe é a principal voz narrativa do coro polifônico feminino que compõe a tessitura do romance. Cutrufelli, partindo de dados e fatos históricos, recupera e reinventa o passado para falar de um assunto ainda atual: o papel da mulher na sociedade.

O coro de vozes femininas, ainda, é composto da esposa do filho Pierre, Hyacinthe, da serva, Justine, da jovem republicana que denuncia Olympe, Françoise-Modeste, das crianças como Thérèse e de uma série de personagens que testemunham e ajudam a delinear o clima vivenciado naquela "Paris do terror". Os títulos dos capítulos são dados a partir dos nomes das vozes que narram. Assim, "Hyacinthe", "Olympe", "Hyacinthe", "FrançoiseModeste" e "Justine" são os primeiros e se repetem ao longo da leitura. Tal configuração já apresenta ao leitor a coralidade presente na obra e ajuda- 
o a manter o fio condutor da(s) narrativa(s). Todas essas mulheres dão, por meio de suas falas, traços diferentes da personagem principal Olympe, a partir de pontos de vista variados, contribuindo, assim, para construir o retrato da heroína.

Em Eu vivi por um sonho, há, portanto, um leque de personagens que, a partir do contexto no qual estão circunscritos, percebem e descrevem os acontecimentos que confluem na figura de Olympe. É seguindo essa linha, portanto, que são perfilados para o leitor os vários quadros que remetem àquele período, à vida cotidiana, à vida política, à vida na prisão, com diálogos e discussões de pessoas comuns que se encontram e falam de política, da revolução, da família e dos problemas caseiros. É interessante chamar a atenção para a caracterização feita da realidade dos cárceres, definidos como lugares escuros, sujos e lotados.

Esse resgate do passado é feito não só a partir dos nomes de personagens históricos, como Robespierre, mas também a partir de alguns fatos presenciados ou contemporâneos às vicissitudes de Olympe. Logo no início do romance há o funeral de Jean-Paul Marat, conhecido como "amigo do povo", que é assassinado por Charlotte Corday, presa em 17 de julho de 1793 e condenada à guilhotina:

Para abreviar, ouço bater as bh e nós ainda estamos em casa. Não agüento mais de tanta impaciência, da janela entra um rumor surdo, contínuo, é a multidão que vai se juntando e se demorarmos mais um pouco tenho medo de não ver nada. Isso já me aconteceu na Igreja dos Franciscanos, onde o corpo estava exposto. A multidão se aglomerara a tal ponto que não consegui achar espaço. De longe, de muito longe entrevi jovenzinhas que lançavam flores sobre o leito fúnebre, todas vestidas de branco - como queria ser uma delas! -, enquanto o presidente de uma seção pronunciava um discurso [...] cidadãs, espalhem flores sobre o corpo pálido de Marat! Marat foi nosso amigo, foi amigo do povo, viveu para o povo, pelo povo morreu. Cidadás espalhem flores sobre o corpo pálido do amigo do povo [...] (p. 36).

O romance de Cutrufelli retrata os últimos quatro meses de vida de Olympe, de julho até 3 novembro de 1793, quando ela é guilhotinada. $O$ que se tem desse percurso é o retrato de uma mulher decidida, uma idealista decepcionada com a Revolução. Olympe sente-se traída e é motivada por um sentimento de justiça que a faz escrever e lutar por aquilo que acredita.
Nessa perspectiva, a escrita será a sua maior força: "E aqui estou, manca no corpo e na alma. Porém ainda tenho momentos de firmeza, em que a realidade recobra peso e retoma seu lugar. Os momentos de escrita" (p. 47). Toda força, coragem e vigor que representam essa personagem, em alguns momentos, dividem o espaço com as fragilidades femininas:

- A condenada chorava. Sim, são lágrimas que abrem caminho em meio a frios riachos de chuva, minhas faces as reconhecem pela morna docilidade, pelo modo como correm e deslizam consoladoras até o pescoço, por dentro da camisa, até o esterno. Choro. Por que não deveria? Sou uma mulher, Henri Sanson. Uma mulher que quis ser alguém. É pela beleza deste sonho que eu choro. E porque teria preferido morrer num dia de sol, com os braços soltos e meu pequeno chapéu azul posto maciamente sobre a fronte (p. 302).

Essas também são as últimas palavras de Olympe que "encerram" o livro.

Para a escritora, a multiplicidade de vozes narrantes tem um motivo - a vontade de evitar a estrutura dos romances históricos "tradicionais" -, como afirmou em entrevista dada a Marilia Piccone, por ocasião da publicação em 2008 do romance $D$ 'amore e d'odio, no qual é possível identificar uma estratégia e uma situação muito parecida. Porém, nesta última obra, o conjunto polifônico não tem como objetivo perfilar uma personagem, mas sim delinear a pluralidade de histórias e vozes do século XX. Todavia, mesmo tentando evitar os romances históricos mais "tradicionais", esse tipo de narrativa pode ser considerado uma escolha e, sobretudo, um elemento marcante dentro de toda a obra e do projeto literário de Cutrufelli - a esse respeito é interessante a entrevista da autora publicada no livro Gendering Italian Fiction: Feminist Revisions of Italian History (1999), de Maria Ornella Marotti e Gabriella Brooke.

Há ainda, nas últimas páginas, um "Posfácio (ou quase)", de poucas páginas, no qual Maria Rosa Cutrufelli afirma ter-se tornado uma "pescadora de vidas perdidas", refazendo-se a Don Delillo. Agora, em vez de resgatar uma parte da história francesa, a autora recupera uma parte das suas lembranças pessoais, durante a década de 1960, quando lia um pequeno livro, Storia dell'emancipazione femminile (História da emancipação feminina). É nessa leitura que ela se depara com o texto da Declaração de Olympe de Gouges, uma descoberta juvenil que traz alguns questionamentos: "[...] mas então existe uma falsa igualdade? E quem era aquela 
mulher que soubera discernir o verdadeiro do falso?" (p. 308). São talvez essas mesmas indagações que povoam e nutrem a ficção de Cutrufelli. É com este livro, que chegou a ser finalista na ltália do famoso Prêmio Strega, em
2004, que a escritora italiana é apresentada ao público brasileiro.

Patricia Peterle Universidade Federal de Santa Catarina 